\title{
Nephrocalcinosis and Placental Findings in Neonatal Bartter Syndrome
}

\author{
Hidehiko Maruyama, MD, $\mathrm{PhD}^{1} \quad$ Yoko Shinno, MD, $\mathrm{PhD}^{2} \quad$ Kaori Fujiwara, $\mathrm{MD}^{1} \quad$ Akie Nakamura, $\mathrm{MD}^{3}$ \\ Toshihiro Tajima, MD, $\mathrm{PhD}^{3}$ Makoto Nakamura, MD ${ }^{1}$ Misao Kageyama, MD ${ }^{1}$
}

${ }^{1}$ Department of Neonatology, National Hospital Organization, Okayama Medical Center, Okayama, Japan

2 Department of Pathology, National Hospital Organization, Okayama

Medical Center, Okayama, Japan

${ }^{3}$ Department of Pediatrics, Hokkaido University School of Medicine,

Sapporo, Hokkaido, Japan

Am J Perinatol Rep 2013;3:21-24.
Address for correspondence Hidehiko Maruyama, MD, PhD, Department of Pediatrics, Kochi Health Sciences Center, 2125-1 Ike Kochi Kochi 781-8555, Japan (e-mail: maruyamahidehiko@gmail.com).

\author{
Abstract \\ Keywords \\ - indomethacin \\ - nephrocalcinosis \\ - neonatal Bartter \\ syndrome \\ - trophoblast basement \\ membrane
}

Neonatal Bartter syndrome (NBS) is an inherited renal tubular disorder associated with hypokalemic alkalosis. Here we report a case of genetically diagnosed NBS. Polyhydramnios was noted at 26 weeks. A boy was born at 31 weeks and 1 day, weighed $1344 \mathrm{~g}$, and had an Apgar score of 8/8. We initiated indomethacin (IND) at a dose of $0.2 \mathrm{mg} / \mathrm{kg} / \mathrm{d}$ on day 31 , and increased it to approximately $3 \mathrm{mg} / \mathrm{kg} / \mathrm{d}$. However, his urinary calcium ( $\mathrm{Ca}$ ) levels remained unchanged. At 4 months of age, nephrocalcinosis was detected by ultrasound. The placenta weighed $700 \mathrm{~g}$ (+2.7 standard deviations). Although the proportion of terminal villi was consistent with the gestational age, many of them exhibited poorly dilated capillaries. Hemosiderin pigment was seen throughout the amniochorionic connective tissue and along about $50 \%$ of the trophoblast basement membrane (TBM). Von Kossa stain revealed the corresponding area of mineralization along the TBM. In our opinion, urinary Ca levels were high and did not change after IND initiation, indicating that nephrocalcinosis may be inevitable. Enhanced inflow of maternal plasma through the basement membrane would cause Ca deposition, given that the same finding was obtained in the case with polyhydramnios. The same mechanism would also explain the hemosiderin pigment distribution.
Bartter syndrome is an inherited renal tubular disorder associated with hypokalemic alkalosis. The symptoms of neonatal Bartter syndrome (NBS) are polyuria, polyhydramnios, and premature birth. Characteristic laboratory findings include hyperreninemia, hyperaldosteronism, and high prostaglandin E2 (PGE2) production. $^{1-3}$ In NBS, activation of cyclooxygenase (COX) increases PGE2 production. Thus, in addition to water and electrolyte supplementation, the COX inhibitor indomethacin (IND) has been used to treat NBS. ${ }^{4-7}$

Here, we discuss nephrocalcinosis, one of the clinical characteristics and placental findings in a patient with NBS. Written informed parental consent was obtained for this study.

received

April 21, 2012

accepted after revision

July 11,2012

published online

December 3, 2012

\section{Case Report}

The 27-year-old mother had two healthy children from a nonconsanguineous marriage. Polyhydramnios was noted at 26 weeks of gestation. No distinct anomaly was detected by ultrasound. Amniotic fluid was removed three times (1500, 1300 , and $2800 \mathrm{~mL}$ ) and was not bloody. Amniotic fluid analysis revealed a 46,XY karyotype. Labor began just after the third removal of amniotic fluid. Cesarean section was performed as the baby was in the transverse position. The boy was born at 31 weeks and 1 day, weighed $1344 \mathrm{~g}$, and had an Apgar score of 8/8. No anomalies were detected, and we were able to insert a tube into the stomach.

Copyright $\odot 2013$ by Thieme Medical Publishers, Inc., 333 Seventh Avenue, New York, NY 10001, USA.

DOI http://dx.doi.org/ 10.1055/s-0032-1329682. ISSN 2157-6998. 
Table 1 Laboratory Findings at Birth

\begin{tabular}{|c|c|c|c|c|c|c|c|}
\hline \multicolumn{4}{|c|}{ Blood } & \multicolumn{2}{|c|}{ Urine } & \multicolumn{2}{|c|}{ Amniotic fluid } \\
\hline WBC & $5900 / \mu \mathrm{L}$ & $\mathrm{pH}$ & 7.292 & $\mathrm{Na}$ & $112 \mathrm{mEq} / \mathrm{L}$ & $\mathrm{Na}$ & $131 \mathrm{mEq} / \mathrm{L}$ \\
\hline RBC & $3.95 \times 10^{6} / \mu \mathrm{L}$ & $\mathrm{pCO}_{2}$ & $56.1 \mathrm{~mm} \mathrm{Hg}$ & $\mathrm{K}$ & $5.0 \mathrm{mEq} / \mathrm{L}$ & $\mathrm{K}$ & $4.1 \mathrm{mEq} / \mathrm{L}$ \\
\hline $\mathrm{Hb}$ & $15.0 \mathrm{~g} / \mathrm{dL}$ & $\mathrm{pO}_{2}$ & $34.5 \mathrm{~mm} \mathrm{Hg}$ & $\mathrm{Cl}$ & $106 \mathrm{mEq} / \mathrm{L}$ & $\mathrm{Cl}$ & $106 \mathrm{mEq} / \mathrm{L}$ \\
\hline $\mathrm{Ht}$ & $43.7 \%$ & $\mathrm{HCO}_{3}$ & $26.3 \mathrm{mEq} / \mathrm{L}$ & $\mathrm{Ca}$ & $7.9 \mathrm{mg} / \mathrm{dL}$ & $\mathrm{Ca}$ & $6.1 \mathrm{mg} / \mathrm{dL}$ \\
\hline PLT & $168 \times 10^{3} / \mu \mathrm{L}$ & $\mathrm{BE}$ & $-1.0 \mathrm{mEq} / \mathrm{L}$ & $P$ & $6.5 \mathrm{mg} / \mathrm{dL}$ & $P$ & $3.8 \mathrm{mg} / \mathrm{dL}$ \\
\hline CRP & $0.05 \mathrm{mg} / \mathrm{dL}$ & $\mathrm{Na}$ & $130.8 \mathrm{mEq} / \mathrm{L}$ & $\mathrm{Cr}$ & $1.67 \mathrm{mg} / \mathrm{dL}$ & $\mathrm{Cr}$ & $0.59 \mathrm{mg} / \mathrm{dL}$ \\
\hline BUN & $4 \mathrm{mg} / \mathrm{dL}$ & K & $3.94 \mathrm{mEq} / \mathrm{L}$ & Osm & 229 mOsm & Osm & $257 \mathrm{mOsm}$ \\
\hline $\mathrm{Cr}$ & $0.43 \mathrm{mg} / \mathrm{dL}$ & $\mathrm{Cl}$ & $96.0 \mathrm{mEq} / \mathrm{L}$ & & & & \\
\hline Renin & $>400 \mathrm{pg} / \mathrm{mL}$ & iCa & $1.44 \mathrm{mg} / \mathrm{dL}$ & & & & \\
\hline Aldosterone & 2020 pg/mL & Lactate & $24 \mathrm{mg} / \mathrm{dL}$ & & & & \\
\hline $\mathrm{ADH}$ & $1.0 \mathrm{pg} / \mathrm{mL}$ & Glu & $55 \mathrm{mg} / \mathrm{dL}$ & & & & \\
\hline
\end{tabular}

WBC, white blood cell; RBC, red blood cell; Hb, hemoglobin; Ht, hematocrit; PLT, platelets; CRP, C-reactive protein; BUN, blood urea nitrogen; Cr, creatinine; $\mathrm{ADH}$, antidiuretic hormone; $\mathrm{BE}$, base excess; Osm, osmolarity.

At 4 hours of age, polyuria $(9.8 \mathrm{~mL} / \mathrm{kg} / \mathrm{h})$ was detected. We also observed extensive loss of electrolytes into the urine: $\mathrm{Na}$ $112 \mathrm{mEq} / \mathrm{L} ; \mathrm{K} 5.0 \mathrm{mEq} / \mathrm{L} ; \mathrm{Cl} 106 \mathrm{mEq} / \mathrm{L} ; \mathrm{Ca} 7.9 \mathrm{mg} / \mathrm{dL}$; and creatinine $(\mathrm{Cr}) 1.67 \mathrm{mg} / \mathrm{dL}$ ( - Table 1). Similar proportions of electrolytes were detected in the amniotic fluid. He was given sufficient water and electrolytes. NBS was strongly suspected due to the presence of renin at $>400 \mathrm{pg} / \mathrm{mL}$, aldosterone at $2020 \mathrm{pg} / \mathrm{mL}$, and antidiuretic hormone at $1 \mathrm{pg} / \mathrm{mL}$ in the baby's blood on day 0 .

He suffered from neonatal toxic-shock-syndrome-like exanthematous disease on day 5 due to methicillin-resistant Staphylococcus aureus and was treated with antibiotics. On day 8 , his blood pressure $(65 / 29$ to $41 / 16 \mathrm{~mm} \mathrm{Hg})$ and urine output ( 11.6 to $3.5 \mathrm{~mL} / \mathrm{kg} / \mathrm{h}$ ) decreased. There was the absence of diastolic renal artery flow in the ultrasound, and he was diagnosed with late-onset circulatory collapse. We initiated hydrocortisone (HDC) on day 11 , and subsequently his urine output improved. We attempted to decrease the amount of HDC twice, but without success. On day 31, IND was initiated at $0.2 \mathrm{mg} / \mathrm{kg} / \mathrm{d}$ and was gradually increased to $2.7 \mathrm{mg} / \mathrm{kg} / \mathrm{d}$. After IND initiation, HDC was reduced and finally terminated on day 73. During his hospital stay, plasma aldosterone levels gradually decreased from $2020 \mathrm{pg} / \mathrm{mL}$ on day 0 to 1280 and $935 \mathrm{pg} / \mathrm{mL}$ on days 31 and 69, respectively,

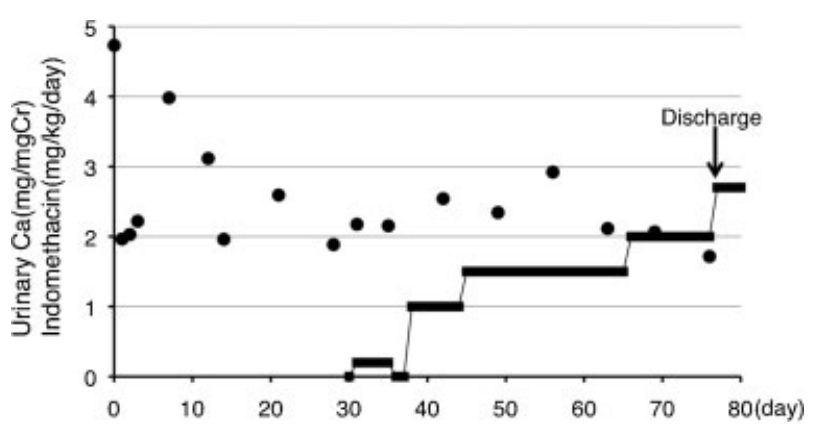

Fig. 1 Urinary Ca (mg/mg Cr, circle marker) levels before and after indomethacin administration ( $\mathrm{mg} / \mathrm{kg} / \mathrm{d}$, square marker). whereas the plasma renin levels were over the measurement range on days 0,31 , and 69 . Ca was given intravenously from day $0(600 \mathrm{mg} / \mathrm{kg} / \mathrm{d})$ and decreased gradually. Breast milk was started at day 0 and reached at $92 \mathrm{~mL} / \mathrm{kg} / \mathrm{d}$ at day 7 . After the late-onset circulatory collapse at day 8 , breast milk decreased. Afterward, the breast milk was increased again and became over $100 \mathrm{~mL} / \mathrm{kg} / \mathrm{d}$ at day 13 . In addition to fortifier, we added calcium lactate at day 19 . We added vitamin D $(0.05 \mu \mathrm{g} / \mathrm{kg} / \mathrm{d})$ at day 20. The serum level of Ca was almost kept from 9 to $11 \mathrm{mg} / \mathrm{dL}$, with the nadir of $8.4 \mathrm{mg} / \mathrm{dL}$ at day 21. Urinary Ca ( $\mathrm{mg} / \mathrm{mg} \mathrm{Cr}$ ) remained high (2 to 3 ) even after IND administration (-Fig. 1). Nephrocalcinosis was not detected by ultrasound during his hospital stay. Urinary Fe was $<0.18 \mathrm{mg} / \mathrm{d}$ on day 14 .

With respect to the auditory brain stem response (ABR), $\mathrm{V}$ waves were not detected at $35 \mathrm{~dB}$ in either ear at the corrected age of 41 weeks. Brain magnetic resonance imaging showed no abnormal findings at the corrected age of 40 weeks.

He harbored a compound heterozygous mutation in exon 8 c.del1100t and exon 10 p.R471X of the SLC12A1 gene encoding NKCC2. Both mutations were new to the Human Gene Mutation Database. We did not determine the functional consequences of our mutants. However, two mutations might cause the disease. One mutation, R471X, which was located in exon 10 , is subjected to nonsense-mediated decay. The other deletion mutation changes the open reading frame after the deletion site. Thus NKCC2 function might be impaired by amino acids substitutions. We provided genetic counseling for his parents; however, they did not want to get their DNA analyzed.

The placenta weighed $700 \mathrm{~g}(+2.7$ standard deviations $){ }^{8}$ Although the proportion of terminal villi was consistent with the gestational age, many of them showed poorly dilated capillaries (-Fig. 2). Hemosiderin pigment was seen throughout the amniochorionic connective tissue and along about $50 \%$ of the trophoblast basement membrane (TBM; - Fig. $\mathbf{3}$ ). Von Kossa stain also revealed the corresponding area of 

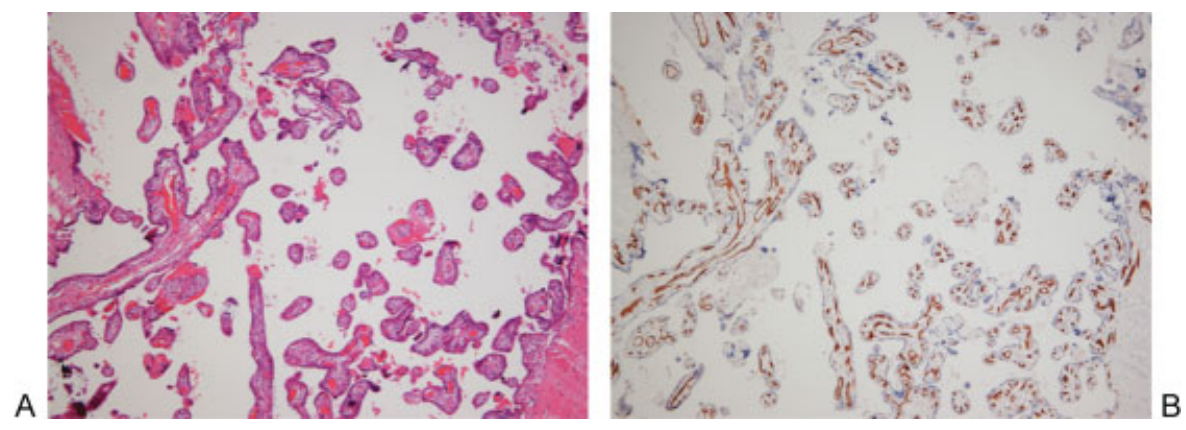

Fig. 2 Hematoxylin-eosin staining of the placenta (A). Although the proportion of terminal villi was consistent with the gestational age, many of them showed poorly dilated capillaries. CD34-positive endothelial cells (B).

mineralization along the TBM ( - Fig. $\mathbf{3}$ ). No vascular damage or interstitial hemorrhage was detected in the villi and the amniochorionic connective tissue.

On day 77 (42 weeks old), he was discharged with IND, $\mathrm{NaCl}$, and potassium glucuronate. At 4 months of age, nephrocalcinosis was detected by ultrasound. At 7 months of age (corrected age: 5 months), the ABR was normal. Catch-up growth and rolling over were detected.

\section{Discussion}

Mutations in ion transport channels lead to decreased Ca reabsorption in patients with NBS, which is similar to that observed in patients treated with loop diuretics. The end result is hypercalciuria, leading to nephrocalcinosis.

Dane et al reported two cases (33 weeks, $1640 \mathrm{~g}$ and 35 weeks, $2420 \mathrm{~g}$ ) where treatment with IND was initiated in the antenatal period. At 18 months of age, the first case had minimal calcification and the second had no calcification, ${ }^{5}$ suggesting that antenatal IND treatment was effective in preventing nephrocalcinosis (- Table 2). In the present case, however, nephrocalcinosis was detected at 4 months of age, and urinary Ca levels did not decrease despite the treatment. Although antenatal IND could prevent nephrocalcinosis, there would be some side effects. ${ }^{9}$ On the contrary, our findings suggest that nephrocalcinosis may be inevitable because IND was not effective in our case. We checked the usage dose of IND in the previous reports. ${ }^{5,6,10}$ It was around 2 to $3 \mathrm{mg} / \mathrm{kg} / \mathrm{d}$, which was too much for us, because we usually use it in dosages of $0.2 \mathrm{mg} / \mathrm{kg}$ for patent ductus arteriosus therapy. So we started at a small dose and increased the dose, taking care of side effects.

In the previous reports, the placental weight was high. ${ }^{5,11}$ Small vessels in the villi showed reduced blood circulation. We believe that villi may grow reactively, thereby increasing placental weight. We could not find the cause in the previous reports. The receptors to angiotensin and PGE2 exist in the placenta. ${ }^{12,13}$ We doubt that there would be the influence of them.

According to Dane et al, fetal renal excretion of Ca could lead to dystrophic calcification with placental involvement, particularly in a subtrophoblastic pattern. ${ }^{5}$ Ernst and Parkash hypothesized that a relatively hypocalcemic fetus would require increased transport of $\mathrm{Ca}$ ions across the placenta and that excesses of Ca due to overloading of the transport system could be deposited beneath the trophoblastic layer. ${ }^{11}$

These theories may explain elevated Ca levels in the amniotic fluid and fetal hypocalcemia-induced increase in motherto-fetus Ca transport. However, the passage of Ca through amniochorionic connective tissue to the TBM as proposed by
Hematoxylin Eosin Berlin Blue

B

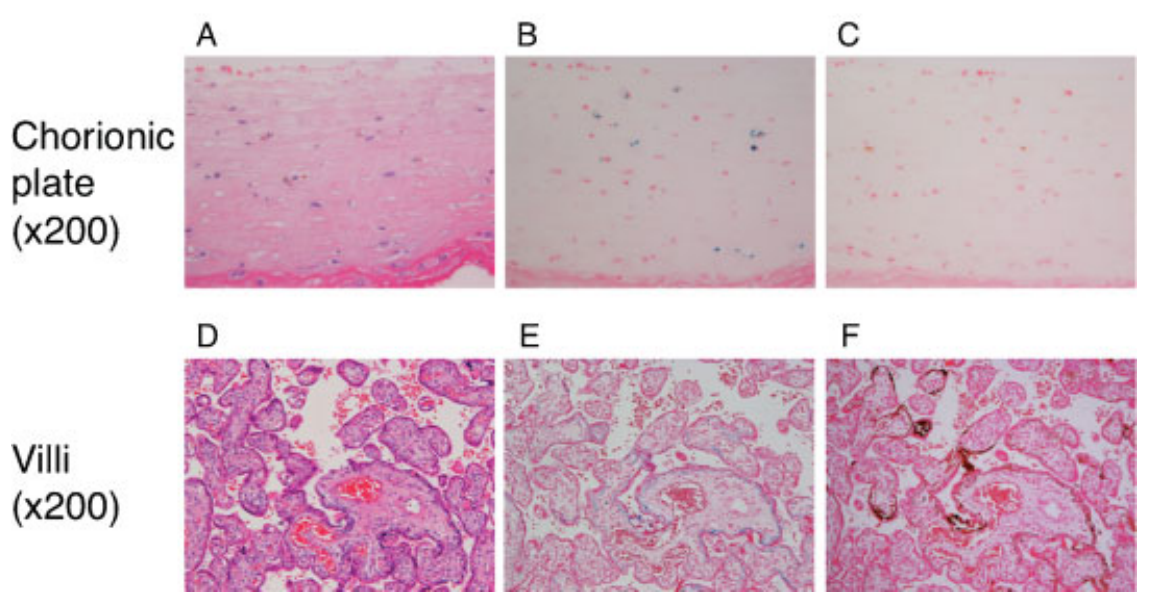

Fig. 3 Placental histology. Hematoxylin-eosin staining (A, D). Hemosiderin pigment deposition seen throughout the amniochorionic connective tissue and along about $50 \%$ of trophoblast basement membrane (B, E). Von Kossa staining along the trophoblast basement membrane ( $\mathbf{C}$, $\mathbf{F}$ ). 
Table 2 Indomethacin Dosages and Nephrocalcinosis in Neonatal Bartter Syndrome

\begin{tabular}{|c|c|c|}
\hline Author & Indomethacin Dosage & Nephrocalcinosis \\
\hline Nakagawa $^{10}$ & $\begin{array}{l}1 \text { st case }(42 \mathrm{wk}): 1 \text { y old, } \sim 3 \mathrm{mg} / \mathrm{kg} / \mathrm{d}(18 \mathrm{mg} / \mathrm{d}) ; 2 \text { y old, } \sim 22 \mathrm{mg} / \mathrm{d} ; \\
5 \text { y old, } \sim 25 \mathrm{mg} / \mathrm{d} ; 16 \text { y old, } \sim 0.5 \mathrm{mg} / \mathrm{kg} / \mathrm{d}\end{array}$ & Not mentioned \\
\hline Konrad $^{6}$ & $\begin{array}{l}\text { 1st case }(28 \mathrm{wk}, 750 \mathrm{~g}): 11 \mathrm{wk} \text { old, } \sim 1.6 \mathrm{mg} / \mathrm{kg} / \mathrm{d} \text {, then } 3 \mathrm{mg} / \mathrm{kg} / \mathrm{d} \\
\text { 2nd case }(35 \mathrm{wk}, 2670 \mathrm{~g}): 7 \mathrm{~d} \text { old, } \sim 1 \mathrm{mg} / \mathrm{kg} / \mathrm{d} \text {, then } 0.2 \mathrm{mg} / \mathrm{kg} / \mathrm{d} \text { due to } \\
\text { oliguria, then } 0.6 \mathrm{mg} / \mathrm{kg} / \mathrm{d}\end{array}$ & $\begin{array}{l}\text { 1st case: }(+) \text { at } 2 \text { mo of age } \\
\text { 2nd case: mild }(+) \text { at } 3 \text { mo of age }\end{array}$ \\
\hline Ernst $^{11}$ & $\begin{array}{l}\text { 1st case ( } 30 \mathrm{wk}) \text { and } 2 \mathrm{nd} \text { case ( } 32 \mathrm{wk}) \text {; Indomethacin was used (dosage } \\
\text { not mentioned) }\end{array}$ & Both cases: $(+)$ \\
\hline Adachi $^{4}$ & $\begin{array}{l}\text { 1st case }(35 \mathrm{wk}, 2340 \mathrm{~g}): 0.33 \mathrm{mg} / \mathrm{kg} / \mathrm{d} \\
\text { 2nd case }(33 \mathrm{wk} ; 1918 \mathrm{~g}) ; 0.1 \mathrm{mg} / \mathrm{kg} / \mathrm{d}\end{array}$ & $\begin{array}{l}\text { 1st case: }(+) \text { at } 1.5 \text { y of age } \\
\text { 2nd case: }(+) \text { at } 87 \mathrm{~d} \text { of age }\end{array}$ \\
\hline Dane $^{5}$ & $\begin{array}{l}\text { 1st case ( } 33 \mathrm{wk}, 1640 \mathrm{~g}): 2 \mathrm{mg} / \mathrm{kg} / \mathrm{d} \text { to mother before birth; at } 2 \mathrm{wk} \text { of } \\
\text { age, initiation of indomethacin; spontaneous intestinal perforation at } \\
3 \text { wk of age } \\
2 \mathrm{nd} \text { case }(35 \mathrm{wk}, 2420 \mathrm{~g}): 1 \mathrm{mg} / \mathrm{kg} / \mathrm{d} \text { to mother before birth; at } 16 \mathrm{~d} \text { of } \\
\text { age, initiation of indomethacin }\end{array}$ & $\begin{array}{l}\text { 1st case: minimal calcification at } \\
18 \text { mo of age } \\
2 \text { nd case: }(-) \text { at } 18 \text { mo of age }\end{array}$ \\
\hline
\end{tabular}

Dane et $\mathrm{al}^{5}$ is difficult to understand. Only a few studies have specifically examined these linear subtrophoblastic deposits. Krohn et al reported increased membrane calcifications in polyhydramnios. ${ }^{14}$ In polyhydramnios, fetal hypovolemia may be caused by increased urine output and intestinal atresia, among others. Accordingly, maternal plasma, including $\mathrm{Ca}$, may pass through the TBM, resulting in Ca deposits.

The hemosiderin deposition pattern was similar to that of $\mathrm{Ca}$, suggesting that the same mechanism may underlie hemosiderin deposition. In other words, increased Fe in the blood and urine caused by enhanced maternal plasma inflow may explain the hemosiderin deposition in the amniochorionic connective tissue. However, increased renal Fe has not been reported, and in our case, the infant did not have much urinary Fe. Furthermore, the amniotic fluid was not bloody. Hemosiderin pigment was seen along about $50 \%$ of the trophoblast basement membrane, which was less than $75 \%{ }^{11}$ But this finding is nonspecific. Thus, the low percentage would not be the problem.

In conclusion, nephrocalcinosis may be inevitable in NBS. Enhanced maternal plasma inflow through TBM could cause Ca deposition, given that the same finding was obtained in the case with polyhydramnios. The same mechanism could account for the hemosiderin pigment distribution.

\section{Acknowledgments}

We thank our colleagues Shigehiro Mori, Hirosuke Morita, Akihito Takeuchi, Eiko Toda, Yoko Yamabe, and Kazue Nakamura at the Okayama Medical Center for their significant contributions to this study.

\section{References}

1 Bartter FC, Gill JR Jr, Frolich JC, et al. Prostaglandins are overproduced by the kidneys and mediate hyperreninemia in Bartter's syndrome. Trans Assoc Am Physicians 1976;89:77-91
2 Bartter FC, Pronove P, Gill JR Jr, MacCardle RC. Hyperplasia of the juxtaglomerular complex with hyperaldosteronism and hypokalemic alkalosis. A new syndrome. Am J Med 1962;33:811-828

3 Gill JR Jr, Frölich JC, Bowden RE, et al. Bartter's syndrome: a disorder characterized by high urinary prostaglandins and a dependence of hyperreninemia on prostaglandin synthesis. Am J Med 1976;61:43-51

4 Adachi M, Asakura Y, Sato Y, et al. Novel SLC12A1 (NKCC2) mutations in two families with Bartter syndrome type 1. Endocr J 2007;54:1003-1007

5 Dane B, Dane C, Aksoy F, Cetin A, Yayla M. Antenatal Bartter syndrome: analysis of two cases with placental findings. Fetal Pediatr Pathol 2010;29:121-126

6 Konrad M, Leonhardt A, Hensen P, Seyberth HW, Köckerling A. Prenatal and postnatal management of hyperprostaglandin $\mathrm{E}$ syndrome after genetic diagnosis from amniocytes. Pediatrics 1999;103:678-683

7 Murakami M, Kudo I. Prostaglandin E synthase: a novel drug target for inflammation and cancer. Curr Pharm Des 2006;12:943-954

8 Nakayama M, Arai H, Takeuchi M, et al. Organ weights, cardiac size in infancy among with placental size and weight [in Japanese]. The Journal of Osaka Medical Center and Research Institute of Maternal and Child Health 1997;13:103-115

9 Sood BG, Lulic-Botica M, Holzhausen KA, et al. The risk of necrotizing enterocolitis after indomethacin tocolysis. Pediatrics 2011;128:e54-e62

10 Nakagawa Y, Toya K, Natsume H, et al. Long-term follow-up of a girl with the neonatal form of Bartter's syndrome. Endocr J 1997; 44:275-281

11 Ernst LM, Parkash V. Placental pathology in fetal Bartter syndrome. Pediatr Dev Pathol 2002;5:76-79

12 Grigsby PL, Sooranna SR, Brockman DE, Johnson MR, Myatt L. Localization and expression of prostaglandin E2 receptors in human placenta and corresponding fetal membranes with labor. Am J Obstet Gynecol 2006;195:260-269

13 Williams PJ, Mistry HD, Innes BA, Bulmer JN, Broughton Pipkin F. Expression of AT1R, AT2R and AT4R and their roles in extravillous trophoblast invasion in the human. Placenta 2010;31:448-455

14 Krohn K, Ljungqvist A, Robertson B. Trophoblastic and subtrophoblastic mineral salt deposition in hydramnios. Acta Pathol Microbiol Scand 1967;69:514-520 